\title{
Critical Discourse Analysis of Selected Nigerian Political Hate Speeches
}

\author{
Harriet Chinyere Obiora \\ Department of Linguistics, Igbo \& Other Nigerian Languages, University of Nigeria, Nsukka, Nigeria \\ Sopuruchi Christian Aboh \\ Department of Linguistics, Igbo \& Other Nigerian Languages, University of Nigeria, Nsukka, Nigeria \\ Bridget O. Dioka \\ Centre for Igbo Studies, University of Nigeria, Nsukka, Nigeria
}

\begin{abstract}
The study examines the hate speeches used by the Nigerian politicians within the theoretical framework of Critical Discourse Analysis (CDA). Some of the hate speeches used by the Nigerian politicians are selected and analyzed. The objectives of this study include identifying and investigating the hate speeches using critical discourse analysis. The random sampling is used to elucidate data from Nigerian dailies. The data includes hate speeches used by Nigerian politicians against the opposing parties or individuals. The methodology for this research is the descriptive approach. The study finds out that the hate speeches are seen in this study as the use of accusations and judgments, mockery and degradation, propagation and solving problems using disdain statements and the use of rhetoric by the members of All Progressive Congress (APC) and People Democratic Party (PDP) in Nigeria to show power and dominance over one another.
\end{abstract}

Index Terms-hate speeches, political discourses, APC, PDP, critical discourse analysis

\section{INTRODUCTION}

We live in a society where language has a strong influence on lives, opinions and beliefs of the people. The essence of language in communication cannot be over emphasized. Language is very important in the implementation of successful democratic rule in any country. "Language is used to serve variety of needs which are either negative or positive in every society" (Eze, 2015, p. 1). Language is seen as a double-edged sword that should be used tactfully as it could be used to destroy and soothe. Ajalie (2007) observes that language can be used to build a very strong nation and language can be used to tear nation apart. The use of language in speech or writing can be used to influence or incite people. Hate speech is any speech used to reduce or lower the respect given to a person or persons based on their race, gender, sexuality, ethnicity and influence or condition the individual to acts of violence. In Nigeria, it is at the heat of the election period or campaign period that most individual slander or insults the political leaders, protests against government policies and propagates against the government. People have been arrested in this country for speaking against the Nigerian government on social media. Though, some of these media information are doctored. Other speeches from some government officials that subordinate their oppositions came to be real. These set of rulers have the aim of achieving their aims through disdain statements. These disdain statements are more achieved through social media. This might be one of demerits of social media in the world and Nigeria in particular. Hate speeches are seen all over the world especially during electoral processes. Ezeibe (2015) avers that hate speech is any speech that is defamatory and can stimulate violence. In accordance to Neisser $(1994$, p. 337) hate speech refers to "all communications (whether, verbal, written, symbol) that insults a racial, ethnic and political group whether by suggesting that they are inferior in some respect or by indicating that they are despised or not welcome for any other reasons".

Hate speeches are seen in Nigeria on social media print, visual artistic and in the news during or after the election by the two major ruling parties in Nigeria. They are: APC - All Progressive Congress (the ruling party) and PDP - People Democratic Party (Opposition party).

This work will be analyzed using Critical Discourse Analysis (CDA). The study seeks to identify and analyse the hate speeches the Nigerian politicians are employing to achieve their selfish interests without being opposed. The study shall seek to characterize the mind control strategies used by these two parties in executing their hate speeches, in order to control the mind of the public against the other political party.

The study shall find out how hate speeches are used as instruments of dominance by PDP (opposition party) over their dominant party APC (ruling party) counterparts.

\section{LITERATURE REVIEW}


Political speeches are defined as speeches by the government or candidates in an office in any discussion of social issues or political issues. They are speeches or strategies or techniques that the government officials or candidates in the government offices use to persuade and make the public to believe in them. Political speeches focus on the public or on the opposition party either to convince or to confuse them on a particular political decision.

Hate speeches occur when a religious group or a political movement systematically attack a specific group or groups in the society through social media of any kind. Some of these media involve radio, television stations, newspapers and internet social media. It is a speech that demeans on the basis of race, ethnicity, gender, religion, age, and disability.

Okafor and Alabi (2017) state that hate speeches are words that wound, which can lead to harm or violence. They concluded that hate speeches refer to every discourse that are hateful in nature, which is used to discriminate against an individual based on their social status, gender, ethnicity, race and religion. Ukwueze and Uche (2015) aver that hate speeches ridicule or attack an individual or a group of people. They stated that in the law of same countries, hate speech is verbal and nonverbal expressions, which is forbidden because it incites violence action against or by a protected individual or group. Weber (2009) states that even though there is no universally accepted definition of hate speech, most state governments in Nigeria adopted a legislation banning expressions amounting to hate speech. Aboh (2019) adds that hate speech can occur between two ethnic groups or political parties and can as well occur within an ethnic group or a political party.

\section{THEORETICAL FRAMEWORK}

The theoretical framework used is the Critical Discourse Analysis (CDA). Critical Discourse Analysis is a theory or model that examines power relation in discourse analysis. Bastone (1995) argues that CDA is a model of linguistic analysis that seeks to unravel the ideological constructions that are covert in texts. CDA deals with discourse dimensions of power abuse and the injustice that result from it. Gee (2011, p. 68) notes that CDA goes beyond description to handle "social practices, not just in terms of social relationships, but also in terms of their implications for things like status, solidarity and the distribution of social good and power".

van Dijk (1993) observes that the CDA is a model of discourse that deals with social power of groups or institutions. Agbedo (2011) states that language is a tool for power in the sense that those who possess power make it known through their language and that language serves the function of controlling mind and action. Critical discourse analysts understand the nature of social power and dominance. As such, they formulate ideas about how discourse contributes to production of power. It involves the properties for relations among social groups. According to Gee (2011, p. 9) "CDA goal is not just to describe how language works or even to offer deep explanations, though such discourse comes to the limelight of political and social intervention among the people in the world. They also want to speak to and perhaps, intervene in, social or political issues, problems and controversies in the world. They want to apply their work to the world in some fashion."

Fairclough (1992, p. 64) defines discourse "as a practice not work not just of representing the world but of signifying the world, constituting and constructing the world in a meaning". van Dijk (1997:26) defines ideology as a "shared selfdefinitions of groups that allows group members to coordinate their social practices in relation to other groups. Stibbe (2001, p. 148) affirms that "ideologies are embedded through discourse, influence the individual members' representation of a society's members, which in turn influence their actions.

van Dijk (1993) states that CDA is a type of discourse analytical research that primarily studies the way social power abuse, dominance, and inequality are enacted, reproduced and resisted by text and talk in the social and political context. Fairclough and Wodak (1997: 27-280) summarize the main tenets of CDA as follows: "CDA addresses social problems; Power relations are discursive; Discourse does ideological work; Discourse constitutes society and culture; Discourse is historical; The link between text and society is mediated; Discourse analysis is interpretative and explanatory; Discourse is a form of social action."

\section{EMPIRICAL STUDIES}

Ezeibe (2015) analyzes the hate speech and electoral violence in Nigeria. He analyzes the effects of hate speech on pre, during and post election violence in Nigeria. He observes that the political leaders in Nigeria neglect the provocative tendencies of hate speech so long as it enables them to capture and retain political power and hate speech has been elevated to the status of political campaign strategy. For example, he said that the hate speech has eaten deep into the bone marrows of Nigerians and hatred between the ethnic groups that makeup Nigeria. The hate speech is among the dominant ethnic groups Hausa, Igbo and Yoruba. The Igbo and Yoruba people see the Hausa people as 'abokis' which though means friends but derogatorily, it means a moron. In a similar vein, the Hausa and the Yoruba people see the Igbo people as 'anyamiri' meaning lovers of money while the Hausa and the Igbo people see the Yoruba people as 'ndị ofe mmanụ' meaning cowards and saboteurs. He concluded that the independent national electoral commission and other civil society organizations should identify and prosecute individuals and organisations that breached the relevant laws governing electoral campaigns and public speeches in Nigeria.

Abiodun, Olusola and Kehinde (2017) investigate hate speech during the 2015 general elections in Nigeria. They observed that during the 2015 general elections in Nigeria, that the political environment was intensified with different 
adverts and propaganda messages. The media organizations in Nigeria are used as vehicles and channels of expression and propaganda. They noted that these messages had element of hate speeches, which were targeted at ridiculing the opponents \& opposition parties. They evaluated the extent at which hate speeches were used during the 2015 general elections in Nigeria. For example, they analyzed the speech made by the Kastina State Governor, Ibrahim Shema, where he urged his supporters to reprise any provocation by the opposition and to kill them like they kill cockroaches. They concluded that the political actors that engaged in the use of hate speeches during electioneering should be punished according to the electoral laws of the country.

Agbedo (2008) uses CDA perspective for analysing the communicative characters of manipulations in President Umaru Musa Yar adua's 2001 budget speech. He observes the analysis of 2001 budget speech of President Umaru Musa Yar'Adua as presented to the session of the National Assembly of Nigeria as showing manifestations of manipulation at the different levels of language. He shows the semantics, syntactic and pragmatic levels of manipulation \& the effect it has on the recipient's mental models as instance of an abuse of ideological power.

Agbedo (2011) uses a CDA perspective of fuel subsidy removal and the mind control game in Nigeria. In his paper, he tends to characterize the discourse of oil subsidy removal as a fundamental component of economic reforms in Nigeria while the dominant group represented by the federal government canvasses capitalist - driven free mercerization of the economy, the dominated group represented by the labour unions, civil society groups and their negative effects on the poor masses in Nigeria.

Agbedo, Obiora \& Ahamefula (2016) investigate regulated women and manipulative language use in African proverbs: A critical Discourse Analysis perspective. They analyzed African proverbs but with particular focus on Igbo proverb as a discourse form. For example

a. Nwanyi leda di ya anya, Ike akpo ya nku - interpretation: when a woman despises her husband, she loses favour from him, and she suffers.

This proverb that is contemptuous of the woman and feminist generally links a woman's success directly to the mercy of the husband. The implication of this statement goes to becloud the minds of women in our society with the perverted indoctrination that womanhood, wife hood and successes attached to them do derive directing from the grace of the husband. They observed that there are elements of oppression and male dominance in some Igbo proverbs that relate to women and recommends a change in the way the society views women to check the undue regulations of women.

Agbedo (2012) studies power manifestations and manipulations in interactive discourses: evidence from Ezikeoba Elders council. Agbedo relies of Critical Discourse Analysis (CDA) perspective to discern the linguistic forms that create unequal balance of power relations and determine the extent to which the traditional judicial system can be listed in the interpretation of interactional power. As Agbedo further observes the interactional power as follows: asymmetrical employment of politeness strategies, address forms, prerogative use of proverbs resources/topic selection and sustenance use of evaluative statements, negotiation on speaking turns and speaking rights, questioning, over statement of power and dominant interpretive framework. He concluded that these are the interpretation of the different power equations that exist in Ezikeoba Elders council.

\section{Data PResentation And Analysis}

\section{A. Data}

\section{Text 1}

The defections that hit the All Progressive Congress (APC) were due to the fact that the APC at the Federal Government level has failed Nigerians. He declared that the (APC) Federal Government runs on vindictiveness, intimidation and illegality. The defections are due to failure of APC Federal Government (Ref. Governor Wike on July 28, 2018 by Emmanuel Okogba Vanguard news online.www.vanguardngr.com).

\section{Text 2}

"Ekiti is a no go area, I have been your governor for the past four years and there has been no herdsmen attack or violence" (Ref. Ekiti is a no go area, fayose warns APC on July 7, 2018, www.vanguardngr.com).

Text 3

The Governor of River State, Gov. Wike stated that the police high command has promoted the Sars and the Assistant Commissioner of Police over their criminal role in the rigging of rerun elections on December, 2016 and beating INEC officials, Democracy in Nigeria has gone. "The police are the one promoting crime in Nigeria. Most of the kidnapping in the country are done by the police". We cannot continue like this enough is enough! APC has made it a policy to intimidate and destroy the judiciary. (Ref. Wike accuses APC of laying structures to rig 2019 election, August 14, 2018, www.punchng.com).

\section{Text 4}

"With PDP's claim on the press statement, it is deliberately attempting to divert public attention from the comical performance put up by Governor Ayodale Fayose". The story of how Gov. Fayose used the security agencies to manipulate the last election is still fresh in the memory of the people. "Winning a free and fair election is a strange territory to him and that is why he is looking stranded, "it is therefore mischievous of PDP to continue to claim that the police assaulted Fayose on Wednesday after Fayose himself apologized to the police for lying against their officers" 
(Ref. Ekiti election alleged attack on Fayose is a comical performance. The above statement culled from the APC national secretary, Bolaji Abdullahi on 12/08/2018 by Gbenga Bada Premium Times, Tribune online).

\section{Text 5}

"On this Ekiti election, President Buhari demonstrated truly what is not a Democratic dispensation, but a dictator and fascist pet excellence," it is only Buhari who will pride himself with the security shooting sporadically at polling centres, scaring people to pave way for the APC thugs to snatch ballot boxes. The president should bury his head in shame for using the Police, Army, Nigeria security, Civil Defence Corps and INEC to snatch the mandate given to Olusola \& deliver it to Fayemi".

"Feyemi's victory is a day light robbery, a brazen subversion of the will of the people and a direct assault on our democracy" (Ref. I don't lose battles; Fayose reacts to Ekiti Election Result, attacks Buhari by Akinola Ajibola, July 16, 2018. Pulse. nglogo).

\section{Text 6}

"As your Governor I will never surrender your mandate and abiding interest of our state to our enemies who seek to keep us enslaved and plundered even at the pain of death. Habile Joshak shamelessly claimed that they acted to the Governor".

"Today's brutal actions were therefore carried out in furtherance of the deliberate plan to intimate the people of Ekiti State in order to facilitate the actualization of the devilish intentions of the enemies of democracy" (Ref. Gov. Nyesom Wike of Rivers State condemned the brazen attack on Ekiti State by the Nigerian police - July 11,2018 www.vanguardngr.com).

Text 7

"That is a cheap talk and Nigeria should not regard it. I think that has become Fayose style of talk and Nigerians must never take those kinds of talk serious because is capable of creating confusion in the system (Ref. Fayose's remark on Buhari is a hate speech as written by Okorocha, Leon Usigbe in Augsut 14, 2018 on Nigerian tribune).

\section{Text 8}

"Three years down the line, Nigeria had become a war zone because the present governments alleged in competence. There is no way APC will win, look at the country, Are we united, Are we stable, Are we prosperous? Are we secured? We have become a world embarrassment; we are becoming an ancient nation. There is no way Buhari will come back no matter, what he does, because he knows he is a contraption who ride on the notions of the Nigerian people based on blackmail, sentiment and hate speech" (Ref. Governor Lamido: President Buhari came to power through blackmail, hate speech stated by Mahmud Dan Fulani, March 23, 2018).

In the next section, we shall explain the disdain between the ruling party (APC) and the opposition party (PDP) to analyze and determine the extent or the strategy used by both parties to control the mind of the people by the more powerful group to reproduce dominance and social inequality.

\section{B. Accusations and Judgments as a Strategy Used by the Opposition Party (PDP)}

van Dijk (1997) states that one of the senses of ideology is a mode of thought and practice developed by dominant groups in order to reproduce and legitimatize their domination. In the texts $1-3$, the opposition party (PDP) used all these words to denigrate the person or dignity of the group or persons involved. Governor Wike pointed out that the ruling party (APC) runs their government on illegality and intimation, Fayose stated that the invasion of the herdsmen attack on Ekiti State is due to the APC government and Wike accuses the APC government on using the police in promoting the crime in the country like kidnapping, killings and also promoting the SARs and the commissioner of police over their criminal role in rigging the election. Using all these invective words on the ruling party (APC) is to run them and disparages the party. But the PDP (opposition party) members, Governor Wike and Governor Fayose, with the rest of PDP party members did not see it as a hate speech but as a speech that will promote or give their own party an edge to the opposition party (APC) while the opposition party members see it as an offensive statement. Dijk shows how discourse structure may influence the formation and change of mental and social representation, that the dominant groups control public discourse, its structure and have more control over the minds of the public at large.

1. The use of mockery and degrading statements

Rogers et. al (2005:37) analysis of this dimension involves exploration of the ways in which discourses operate in various domains of the society. Text 4,7 , and 8 shows the use of hate speeches between the APC candidates, Bolaji Abdullahi, Okorocha and PDP candidate, Governor Lamido. APC secretary stated that PDP are trying to divert the public attention through their comical performance over their claim. Okorocha stated that Fayose's talks are cheap and should not be regarded by Nigerians, and Fayose's kind of talk is capable of creating confusion in the system. On the other hand, Lamido states that Nigerian had become a war zone due to the APC incompetence, we have become a world of embarrassment and that Buhari is a contraption, are we united? Are we secure? Are we stable? Who ride on the notions of the Nigerian people based on blackmail, sentiment and hate speeches?

For Bolaji to use such statement on the PDP members as being a comical performance is a derogatory expression of qualifying the PDP's as being comedians. Okorocha's statement for describing a notable politician like Fayose as making a cheap statement that is capable of creating confusion in the system is a kind of criticising the person of Fayose in the public as making a cheap statement, but low statement are statements made by people with poor intellectual is a degrading statement. van Dijk (1995a) observes that variations of relevance or importance of a news items are open to 
ideological control. For instance, information that is inconsistent with the interests of powerful groups may be downgraded. Lamido's statement against Buhari has made somebody like the President of the country, Buhari to lose his dignity and self respect. Lamido used conundrum questions in other to win the mind of the (publics), Nigerians against their President, Buhari. He stated that Buhari is not compliance to the Nigerians due to his blackmail and hate speeches. While describing the President Buhari as a blackmailer that uses hate speeches in appropriate and unreasonable statements make the President looks worthless to the people of Nigerian.

Bolaji, Okorocha and Lamido's statements are statements that cause somebody (groups) to lose their dignity and appear foolish to the public. These statements influence the mental representations of these parties, APC and PDP. These mental representations are part of what van Dijk (1997) calls social cognition because members of a society share them through participation in, and exposure to discourse. Using such malign statements against either APC or PDP has been realized as weapons of dominance to the opposition party.

2. The use of propaganda and solving problems by using disdain statements as a mind control strategy

Damico et al (2005) see power and its manipulations in the social and cultural contexts in this modern society as being pervasive. Fayose noted it when he describes Buhari as dictator, fascist per excellence and using APC thugs to snatch the boxes in winning the Ekiti election with his power everywhere. Fayose stated that the President should bury his head in shame for using the police, army, Nigerian security, civil defense corps and INEC to snatch the mandate given to Olusola and deliver it to Fayemi. Here, Fayose uses such exaggerated statement to brainwash the public against the President in the results of Ekiti election on the actual statement of Fayose it runs thus: "Fayemi's victory is a day light robbery, a brazen subversion of the will of the people and a direct assault on our democracy".

Ofshe (2003) state that the minds control is a systematic manipulation of psychological and social influence, where a group or individual systematically uses manipulative methods to persuade others to conform to the wishes of the manipulators, often by causing harm to the person being manipulated. Fayose calling Fayemi's victory a day light robbery is an inflammatory statement and that Fayemi's victory is shameful by trying to or destroying the political system of the people's will and a direct violent attack on the system of the government. Here, Fayose is trying to manipulate and influence the minds of the public against the (APC) and the president by calling Fayemi's victory a day light robbery. The members of the opposition party (PDP) may see the statement as a mere word but the members of the ruling party (APC) will see it as a hate speech. The use of such statement only fosters a complex inferiority for the (APC) members making them to feel very ashamed for destroying the political system.

3. The use of rhetoric

Text 6 shows how the Governor Nyesom Wike of the Rivers State is trying to use language in an impressive way to influence the people of Ekiti State and the public.

"As your Governor I will never surrender your mandate and abiding interests of our state to our enemies, who seek to keep us, enslave and plundered even at the point of death". Gov Wike uses conviction as his own way of influencing the public against the APC by belittling them.

Van Dijk (1991) exposes how racists, sexists and other ideologies are expressed in discourse through demeaning words that belittle other discourse participants. Wike continued "Habila Joshak shamelessly claimed that they acted to the Governor. Today's brutal actions were therefore carried out in furtherance of the deliberate plan to intimidate the people of the Ekiti State in order to facilitate the actualization of the devilish intentions of the enemies of democracy". Wike uses negative words or information that is against the APC government to influence the public and the Rivers State people in favour of their PDP counterparts. Wike uses such statement to influence the public against the APC government. The opposition party (PDP) did not consider the statement as being offensive but their counterpart the ruling party (APC) see it as a hate speech by calling them the enemies of democracy. Nielsen (2002) avers that the degradation and humiliation brought by hate speech can silence the victims and therefore reinforce existing hierarchies in society.

\section{CONCLUSION}

This study has looked at selected Nigerian political hate speeches and how some hate discourses are deployed to show social dominance and to create unequal power relations between the APC (ruling party) and the PDP (opposition party). The study shows the social power of group or groups or institutions as a central notion in most studies in CDA. The analysis reveals the extent which the dominant party in Nigeria politics use all manner of hate speeches to influence and manipulate the public over the dominated group. While the dominant group is represented by the opposition party (PDP) and the dominated group is represented by the ruling party (APC). Van Dijk (1996) states that social power to have (more or less) power by the group or individual to be able to control the acts and minds of other groups. An example is seen in Nigeria where the members of the ruling party (APC) are deflecting to their opposition party (PDP). The result of the study also indicates that there are elements of breach of laws, intimidations, disdain languages and violation of rights of the dominated groups. Perhaps, the objectives of the study have been achieved from the findings. In Nigeria, the media, cultural, religious and ethnic groups also aggravate the situation by making public hate speeches against each other. The study recommends that another researcher continues with a conversational analysis of selected Nigerian political polite speeches. 


\section{REFERENCES}

[1] Aboh, S. C. (2019). Political discourse analysis of hate speeches in Nigeria. MA dissertation, Department of Linguistics, Igbo and other Nigerian Languages, University of Nigeria, Nsukka.

[2] Abiodun, F., Olusola, Y, \& Kehinde, O. (2017). Hate speech and the 2015 General elections in Nigeria. International Journal of Advances in Social Sciences, 4.3, 10-11. Retrieved from http:iiijasos.ocerintjournals.org 948. Accessed on 20th December 2017.

[3] Agbedo, C.U. (2011). Fuel subsidy removal and the mind control game in Nigeria: A critical discourse analysis perspective. Paper presented at 24 the Annual Conference of the Linguistics Association of Nigeria (LAN), Bayero University, Kano.

[4] Agbedo, C.U. (2012). Power manifestations and manipulations in interactive discourse: Evidence from Ezikeoba elder's council. Journal of Research on Humanities and Social Sciences, 2 (27), (1-10)

[5] Agbedo, C., Obiora, H \& Ndubuisi, O. (2016). Regulated women and manipulative language use in African proverbs: A critical discourse analysis perspective. Journal of Humanities and Cultural Studies, 1, $37-60$.

[6] Ajalie, C.I. (2007). Promoting positive attitude towards English language learning in globalization. Journal of Linguistics and Literary Studies, 2(1), 110 - 115.

[7] Bastone, R. (1995). Grammar in discourse: Attitude and deniability. In G. cook and B. Seidlhofer, (Eds.), Principle and Practice in Applied Linguistics, 2(1), 97 - 213. Oxford: Oxford University Press.

[8] Damico, J.S., Simmons, M. N \& Hawley, H. (2005). Language and power. In M. J Ball (Eds.), Clinical sociolinguistics (pp. 63 - 73). Oxford: Blackwell Publishers.

[9] Eze, C.N. (2015). A pragmatic study of euphemistic expressions in Igbo. Ph.D. thesis, Department of Linguistics, Igbo \& Other Nigerian Languages, University of Nigeria, Nsukka.

[10] Ezeibe, C. (2015). Hate speech and electoral violence in Nigeria: A seminar paper submitted to the Department of Political Science, University of Nigeria, Nsukka.

[11] Fairclough, N.C. (1992). Discourse and social change. London: Polity Press.

[12] Fairclough, N. L. \& Wodak, R. (1997). Critical discourse analysis. In T. A. van Dijk (Ed.) Discourse studies. A multidisciplinary introduction (pp. 258-284). London: Sage.

[13] Gee, J.P (2011). An introduction to discourse analysis, theory and method. (3 ${ }^{\text {rd }}$ ed.). New York: Routledge.

[14] Neisser, E. (1994). Hate speech in the New South Africa: Constitutional consideration for a land Recovery from Decades of Rational Repression and Violence. South African Journal of Human Rights, 10, 333 - 356.

[15] Nielsen, L.B (2002). Subtle, pervasive, harmful racist and sexist remarks in public as hate speech. Journal of Social Issues, 58, $2-5$.

[16] Ofshe, J.R. (2003). Coercive persuasion and attitudinal change. Encyclopedia of Sociology, 1. New York: Macmillan Publishers

[17] Okafor, V.C. \& Alabi, T.O (2017). A speech analysis of hate speeches in the 2015 general election campaign in Nigeria. International Journal of Research in Humanities, Arts and Literature, 5(6), 61 - 72.

[18] Rogers, R., Malancharuvi, E, Mosley, M, Hui, D. \& Joseph, G. (2008). Critical discourse analysis in education: A review of the literature. A Review of Educational Research, 75(3), 365 - 416.

[19] Stibbe, A. (2001). Language, power \& social construction of animals. Society and Animals, 9(2) $145-161$.

[20] Ukwueze, C.I. \& Uche, A. (2015). The rise of hate \& peace journalism in the Nigerian democratization process: The place of the news media. Communication Panorama African \& Global Perspective, 1 (1), 38 - 50.

[21] van Dijk, T.A. (1991). Racism and the press. London: Routledge and Kegan Paul.

[22] van Dijk, T.A. (1993). Principles of critical discourse analysis. Discourse and Society, 4(2), 83-249.

[23] van Dijk, T.A (1996). Discourse, power and access. In R.C. Caldas-Coulthard and M. Coulthard (Eds.), Texts and practices: Readings in critical discourse analysis (pp. 84 - 104). London: Routledge and Kegan Paul.

[24] van Dijk, T. A. (1997). Discourse studies. London: Sage Publishers.

[25] Weber, A, (2009). Manual on hate speech. Council of Europe Publishing Strasbourg. Retrieved from http://book.coe on $8 / 8 / 2018$.

[26] Wodak, R. \& van Dijk, T. (2008). Racism at the top. Austria: Drava.

Harriet Obiora is a native of Ogbunike, Anambra State. She bagged BA in Linguistics from Ebonyi State University and MA in Linguistics from the University of Nigeria, Nsukka. Harriet specialises in Discourse Analysis and Pragmatics.

She has published "Cognitive semantic analysis of titular names in Ogbunike speech community" in Ikoro Journal.

Mrs. Obiora is a member of the Linguistic Association of Nigeria.

Sopuruchi C. Aboh was born in Aba, Abia State on 20th November. He had his Bachelor of Arts Degree and Master of Arts Degree in Linguistics at the University of Nigeria, Nsukka. Sopuruchi specialises in sociolinguistics and pragmatics.

He has published some articles including: "The ideology of post-truth in Nigerian cities: A discourse historical analysis", Journal of Linguistic Association of Nigeria, 22(1), 64-78 and "A comparative analysis of lexical prepositions in the Ibibio and Igbo languages", Macrolinguistics, 6(9), 36-45.

Mr. Aboh is a member of Pragmatics Association of Nigeria, Nigeria Ecolinguistics Association, and Nigerian Institute of Translators and Interpreters.

Bridget Ogechi Dioka was born in Mbaise, Imo State on the 2nd of February. She's got BA and MA degrees in Linguistics and Igbo language at the University of Lagos, Akoka. She specialises in Semantics and Igbo language. She has published a chapter in 
Chinua Achebe and the convolution of immortality (pp. 75-84). She is also a PhD student in the Department of Linguistics, Igbo and Other Nigerian Languages, University of Nigeria, Nsukka. 